\title{
Formation and Properties of New La-Based Bulk Glassy Alloys with Diameters up to Centimeter Order
}

\author{
Wei Zhang*, Fei Jia and Akihisa Inoue \\ Institute for Materials Research, Tohoku University, Sendai 980-8577, Japan
}

New La-based bulk glassy alloys with superior glass-forming ability (GFA) were synthesized in La-Al-Ag-(Cu,Co,Ni) system. The addition of 5 at $\% \mathrm{Ag}$ to La-Al-Cu ternary base system greatly increases the stability of supercooled liquid as well as the GFA. The largest supercooled liquid region and largest diameter in $\mathrm{La}-\mathrm{Al}-\mathrm{Cu}-\mathrm{Ag}$ quaternary system were of $83 \mathrm{~K}$ and $6.0 \mathrm{~mm}$, respectively, for $\mathrm{La}_{62.5} \mathrm{Cu}_{20^{-}}$ $\mathrm{Al}_{12.5} \mathrm{Ag}_{5}$ alloy. The addition of $\mathrm{Ni}$ or $\mathrm{Co}$ to $\mathrm{La}-\mathrm{Al}-\mathrm{Cu}-\mathrm{Ag}$ alloy is effective for the further increase in GFA. The maximum sample diameter of over $12 \mathrm{~mm}$ was fabricated for $\mathrm{La}_{62.5} \mathrm{Al}_{12.5} \mathrm{Cu}_{10} \mathrm{Ni}_{5} \mathrm{Co}_{5} \mathrm{Ag}_{5}$ alloy. The GFA has better correlation with reduced glass transition temperature. The new La-based bulk glassy alloys exhibit high fracture strength of 640-858 MPa with distinct plastic strains of $0.2-0.4 \%$.

[doi:10.2320/matertrans.48.68]

(Received October 16, 2006; Accepted November 6, 2006; Published December 25, 2006)

Keywords: metallic glasses, lanthanum-based alloy, supercooled liquid region, casting, glass-forming ability, mechanical property

\section{Introduction}

Since the syntheses of bulk glassy alloys in multicomponent $\mathrm{Ln}^{-1}{ }^{1)}$ ( $\mathrm{Ln}$ : lanthanide metal) and $\mathrm{Mg}_{-}{ }^{2)}$ based alloys by the copper mold casting method in 1989, much effort has been devoted to develop a new bulk glassy alloy exhibiting high glass-forming ability (GFA) and useful engineering properties. As a result, bulk glassy alloy systems have been widely extended to $\mathrm{Zr}-,{ }^{3,4)} \mathrm{Fe}-,{ }^{5)} \mathrm{Pd}-,{ }^{6)} \mathrm{Ti}-,{ }^{7)} \mathrm{Co}-,{ }^{8)}$ $\mathrm{Ni}-,{ }^{9-11)} \mathrm{Cu}_{-},{ }^{12-14)} \mathrm{Pt}_{-}{ }^{15)}$ and $\mathrm{Au}^{-16)}$ based alloys. These bulk glassy alloys exhibit unique properties such as high strength, large elastic strain limit, high hardness, good soft magnetic properties, and excellent corrosion resistance. The compositions of the bulk glassy alloys with high GFA are typically close to a deep eutectic composition. ${ }^{17)}$ Consequently, their melting temperatures are much lower than those estimated from interpolation of the alloy constituents' melting temperatures. The resulting low liquidus temperature $\left(T_{l}\right)$ is an attractive parameter for finding a new bulk glassy alloys, because the reduced glass transition temperature $\left(T_{g} / T_{l}, T_{g}\right.$ : glass transition temperature) is an importent factor parameter for GFA. ${ }^{18)}$ The stabilization of bulk glassy alloys against crystallization also results in a large supercooled liquid region, $\Delta T_{x},\left(\Delta T_{x}=T_{x}-T_{g}, T_{x}\right.$ : crystallization temperature), in which the glassy phase first relaxes into a highly viscous liquid before eventually crystallizing. In this temperature region, BMG's are amenable to superplastic processing using netshape processing methods similar to those employed for thermoplastics. ${ }^{19)}$ In addition, the $\Delta T_{x}$ is also an importent parameter that interprets GFA of bulk glassy alloys. $^{20)}$

Recently, the Ln-based bulk glassy alloys have gained considerable interest again because the glassy alloys have lower $T_{g},{ }^{21)}$ large $\Delta T_{x},{ }^{21)}$ high GFA, ${ }^{22-24)}$ low melting temperature, ${ }^{25)}$ good mechanical properties, ${ }^{24,26)}$ and hard magnetic properties. ${ }^{22)}$ It is important for scientific and engineering aspects to develop a new Ln-based glassy alloy with higher GFA and larger $\Delta T_{x}$. Very recently, Ln-based glassy alloy rods with diameters of over one centimeter were

*Corresponding author, E-mail: wzhang@imr.tohoku.ac.jp fabricated. However, the new bulk glassy alloys exhibited narrow $\Delta T_{x}$ which were below $45 \mathrm{~K} .^{23,24)}$

In this paper, we report on the formation, stabilization of supercooled liquid and mechanical properties of a new series of Ln-based glassy alloys in the La-Al-Cu-Ag and $\mathrm{La}-\mathrm{Al}-\mathrm{Cu}-$ $\mathrm{Ag}-(\mathrm{Co}, \mathrm{Ni})$ systems, which show the critical diameters range from 6 to $12 \mathrm{~mm}$, low $T_{g}$ of 398-425 K, large $\Delta T_{x}$ of $65-96 \mathrm{~K}$ and high fracture strength of $640-858 \mathrm{MPa}$ with plastic strain of $\sim 0.4 \%$.

\section{Experimental Procedure}

The alloy ingots were prepared by arc melting the mixtures of pure $\mathrm{La}, \mathrm{Cu}, \mathrm{Al}, \mathrm{Ag}, \mathrm{Co}$, and $\mathrm{Ni}$ metals in an argon atmosphere. The purity of metals was over 99.5 mass $\%$. Alloy ingots were re-melted five times to ensure chemical homogeneity. The mass losses were measured for each ingot after melting and were less than 0.1 mass $\%$. The glassy alloy was produced by copper mold casting for bulk cylindrical rods with diameters of $2-15 \mathrm{~mm}$ and by melt spinning for ribbons with a cross section of $0.02 \times 1.2 \mathrm{~mm}^{2}$. The glassy phase was identified by X-ray diffractometer using $\mathrm{Cu}-\mathrm{K} \alpha$ radiation and thermal stability was examined by differential scanning calorimetry (DSC) at a heating rate of $0.67 \mathrm{~K} / \mathrm{s}$. The melting and liquidus temperatures were measured with a differential thermal analyzer (DTA) at a heating rate of $0.17 \mathrm{~K} / \mathrm{s}$. Mechanical properties were measured with an Instron testing machine. The gauge dimension of specimens was $2 \mathrm{~mm}$ in diameter and $4 \mathrm{~mm}$ in height for compressive test and the strain rate was $5 \times 10^{-4} \mathrm{~s}^{-1}$. The fracture surface was examined by scanning electron microscopy (SEM).

\section{Results and Discussion}

\subsection{Ternary La-based glassy alloys}

Table 1 lists some examples of the newly discovered La-based bulk glassy alloys in an order that reflects the sequential optimization of successive alloy additions which resulted in the improvement of the critical sample diameters.

It has been reported that ternary $\mathrm{La}_{55} \mathrm{Al}_{25} \mathrm{Cu}_{20}$ glassy alloys exhibit a large supercooled liquid region $\left(\Delta T_{x}\right)$ of 
Table 1 Summary of the properties and the critical sample diameters of the new La-based bulk glassy alloys developed in this work.

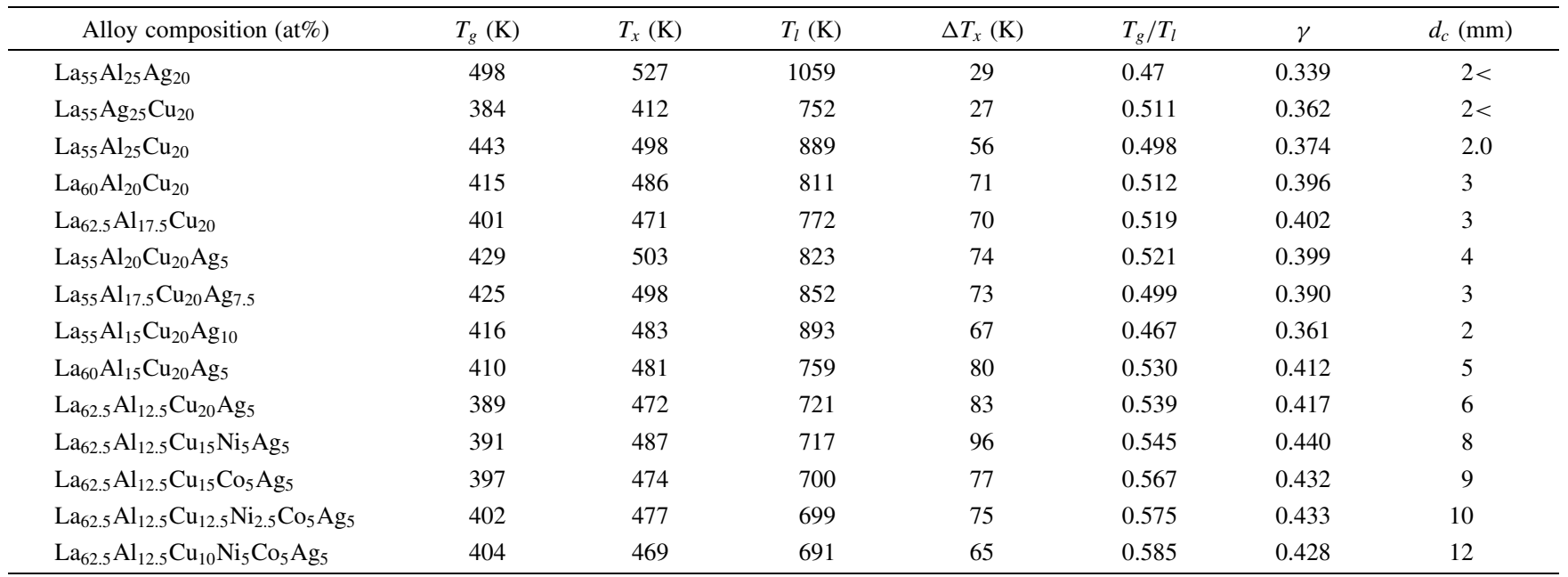

Table 2 The mechanical properties of the new La-based bulk glassy alloys.

\begin{tabular}{lccccc}
\hline \multicolumn{1}{c}{ Alloy composition (at\%) } & $\begin{array}{c}\sigma_{c, f} \\
(\mathrm{MPa})\end{array}$ & $\begin{array}{c}E \\
(\mathrm{GPa})\end{array}$ & $\begin{array}{c}\varepsilon_{c, e} \\
(\%)\end{array}$ & $\begin{array}{c}\varepsilon_{c, p} \\
(\%)\end{array}$ & $H_{v}$ \\
\hline $\mathrm{La}_{55} \mathrm{Al}_{25} \mathrm{Cu}_{20}$ & 858 & 36 & 1.8 & 0.2 & 208 \\
$\mathrm{La}_{55} \mathrm{Al}_{20} \mathrm{Cu}_{20} \mathrm{Ag}_{5}$ & 758 & 42 & 1.8 & 0.2 & 226 \\
$\mathrm{La}_{62.5} \mathrm{Al}_{12.5} \mathrm{Cu}_{20} \mathrm{Ag}_{5}$ & 640 & 36 & 1.9 & 0.3 & 201 \\
$\mathrm{La}_{62.5} \mathrm{Al}_{12.5} \mathrm{Cu}_{15} \mathrm{Ni}_{5} \mathrm{Ag}_{5}$ & 665 & 38 & 1.7 & 0.3 & 198 \\
$\mathrm{La}_{62.5} \mathrm{Al}_{12.5} \mathrm{Cu}_{15} \mathrm{Co}_{5} \mathrm{Ag}_{5}$ & 670 & 38 & 1.7 & 0.4 & 204 \\
$\mathrm{La}_{62.5} \mathrm{Al}_{12.5} \mathrm{Cu}_{10} \mathrm{Ni}_{5} \mathrm{Co}_{5} \mathrm{Ag}_{5}$ & 678 & 39 & 1.7 & 0.2 & 201 \\
\hline
\end{tabular}

over $50 \mathrm{~K}$, leading to the formation of glassy rod specimens. ${ }^{26)}$ We discovered new $\mathrm{La}-\mathrm{Cu}-\mathrm{Ag}$ and $\mathrm{La}-\mathrm{Al}-\mathrm{Ag}$ ternary glassy alloys, which also show a distinct glass transition, followed by a supercooled liquid region and then exothermic reactions due to crystallization. Figure 1 show DSC curves of the melt-spun $\mathrm{La}_{55} \mathrm{Ag}_{25} \mathrm{Cu}_{20}, \mathrm{La}_{55} \mathrm{Al}_{25} \mathrm{Ag}_{20}$ and $\mathrm{La}_{80-x} \mathrm{Al}_{x} \mathrm{Cu}_{20}(x=17.5,20$ and 25$)$ glassy alloys. The La-Cu-Al glassy alloys exhibit large $\Delta T_{x}$ of over $55 \mathrm{~K}$, and the largest $\Delta T_{x}$ was $71 \mathrm{~K}$ for $x=20$ alloy. The $\mathrm{La}-\mathrm{Cu}-\mathrm{Ag}$ and La-Al-Ag alloys show small $\Delta T_{x}$, e.g., $29 \mathrm{~K}$ for $\mathrm{La}_{55} \mathrm{Al}_{25} \mathrm{Ag}_{20}$ and $27 \mathrm{~K}$ for $\mathrm{La}_{55} \mathrm{Ag}_{25} \mathrm{Cu}_{20}$ alloy. We examined the GFA of the ternary alloys by copper mold casting. Although the critical rod diameters for formation of the glassy phase are below $3.0 \mathrm{~mm}$ for the ternary alloys as summarized in Table 1, higher GFA and larger $\Delta T_{x}$ are expected to be obtained for $\mathrm{La}-\mathrm{Al}-\mathrm{Cu}-\mathrm{Ag}$ quaternary alloys. ${ }^{17,19)}$

\subsection{Quaternary La-Al-Cu-Ag glassy alloys}

We first examined the effect of Ag addition on the thermal stability of supercooled liquid and GFA of the ternary La-Cu$\mathrm{Al}$ alloys. Figures 2 and 3 show DSC and DTA curves of the quaternary La-Cu-Al-Ag glassy alloys. From these DSC scans and Table 1 , it is seen that all the $\Delta T_{x}$ remarkably increase by the addition of a small amount of $\mathrm{Ag}$. With addition of $\mathrm{Ag}$ to $\mathrm{La}_{55} \mathrm{Al}_{25} \mathrm{Cu}_{20}$, the $\Delta T_{x}$ increases from $56 \mathrm{~K}$ at 0 at $\% \mathrm{Ag}$ to $74 \mathrm{~K}$ at 5 at $\% \mathrm{Ag}$, and then decreases with a further increase in $\mathrm{Ag}$ content. By the $5 \mathrm{at} \% \mathrm{Ag}$ addition to $\mathrm{La}_{60} \mathrm{Al}_{20} \mathrm{Cu}_{20}$ and $\mathrm{La}_{62.5} \mathrm{Al}_{17.5} \mathrm{Cu}_{20}$ alloys, the $\Delta T_{x}$ also increases from 71 to $80 \mathrm{~K}$ and 70 to $83 \mathrm{~K}$, respectively. It is

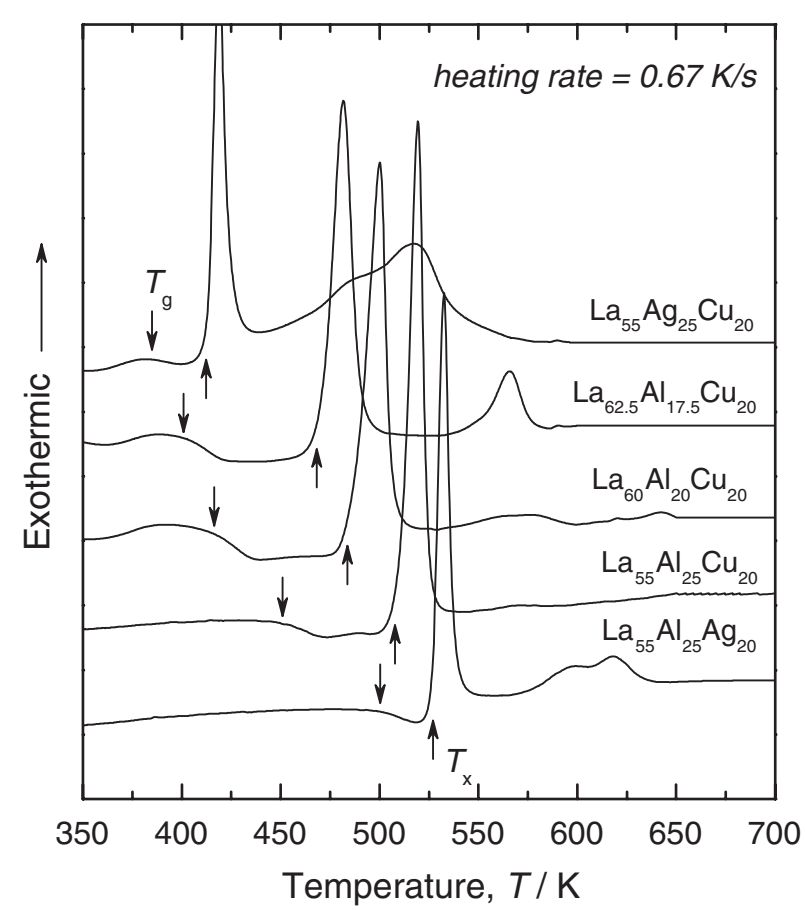

Fig. 1 DSC curves of melt-spun La-Al-Cu, La-Al-Ag and La-Ag-Cu glassy alloys.

therefore concluded that the addition of a small amount Ag to $\mathrm{La}-\mathrm{Cu}-\mathrm{Al}$ ternary glassy alloys is very effective for an increase in $\Delta T_{x}$, i.e., stabilization of supercooled liquid against crystallization.

From Fig. 3 and Table 1, it is seen that the $T_{l}$ values of the ternary La-Cu-Al alloys significantly decrease by the addition of a small amount of $\mathrm{Ag}$. By $5 \% \mathrm{Ag}$ addition to $\mathrm{La}_{55} \mathrm{Al}_{25} \mathrm{Cu}_{20}, \mathrm{La}_{60} \mathrm{Al}_{15} \mathrm{Cu}_{20}$ and $\mathrm{La}_{62.5} \mathrm{Al}_{12.5} \mathrm{Cu}_{20}$ alloys, the $T_{l}$ decreases from 889 to $832 \mathrm{~K}, 811$ to $759 \mathrm{~K}$ and 772 to $721 \mathrm{~K}$, respectively, resulting in an increase of reduced glass transition temperature $\left(T_{g} / T_{l}\right)$ form 0.497 to $0.521,0.512$ to 0.530 and 0.519 to 0.539 , respectively. In addition, the $\mathrm{La}_{62.5} \mathrm{Al}_{12.5} \mathrm{Cu}_{20} \mathrm{Ag}_{5}$ alloy shows an even lower $T_{l}$ of $721 \mathrm{~K}$ and only one distinct endothermic event, indicating that this alloy is rather close to the quaternary eutectic point among the present alloys. 


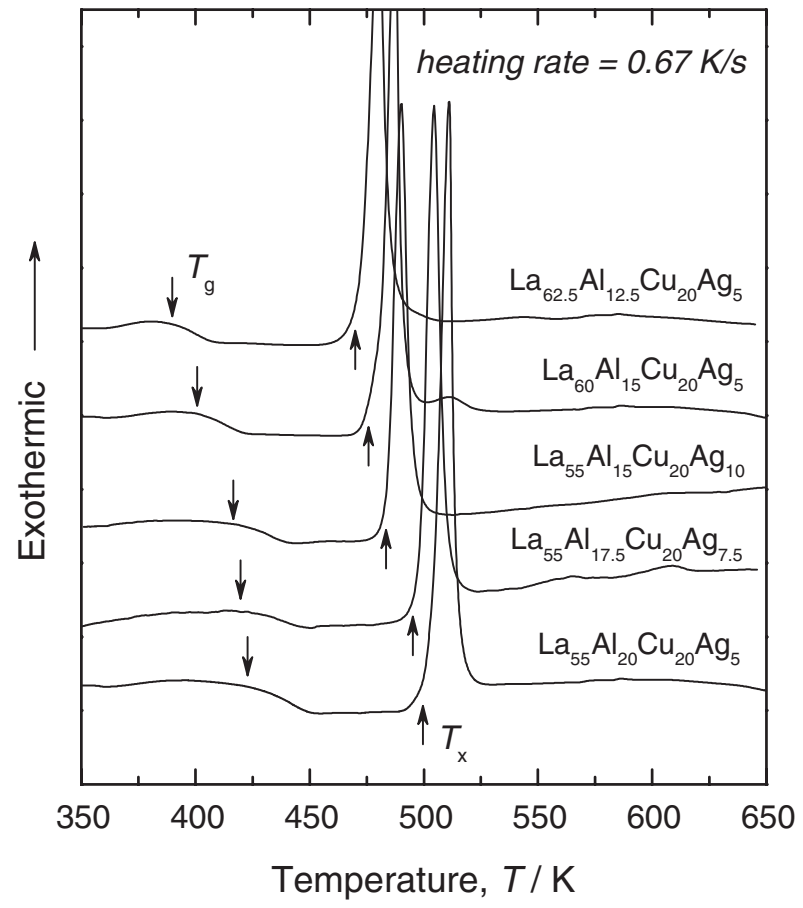

Fig. 2 DSC curves of melt-spun La-Al-Cu-Ag glassy alloys.

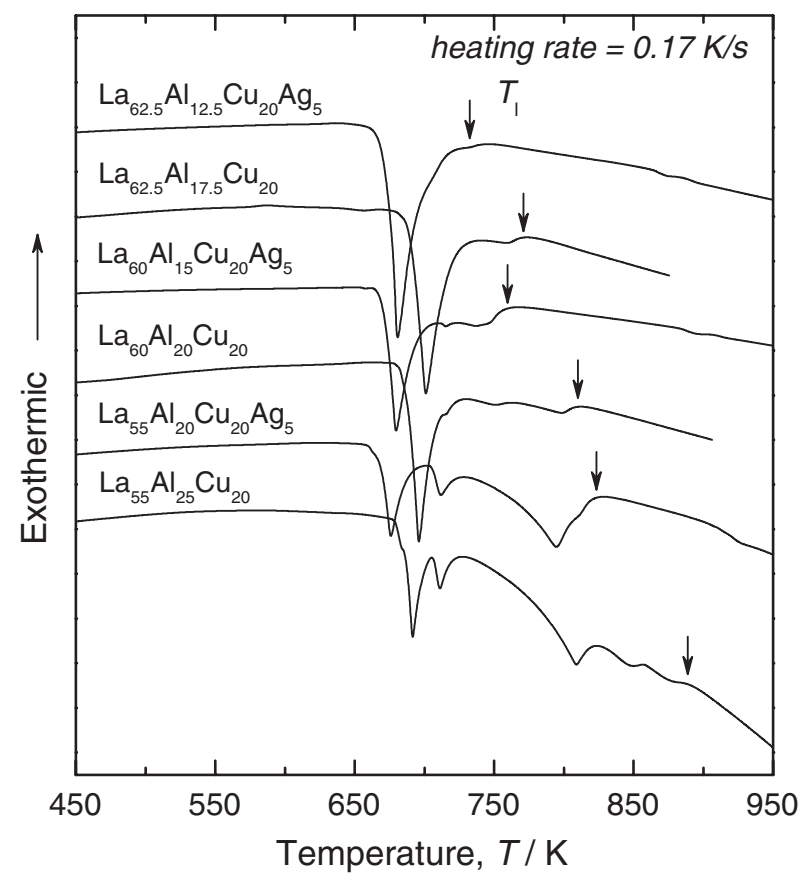

Fig. 3 DTA curves of the La-Al-Cu-Ag alloys.

Figure 4 shows X-ray diffraction patterns of the as-cast $\mathrm{La}-\mathrm{Cu}-\mathrm{Al}-\mathrm{Ag}$ alloy rods with diameters ranging from 3.0 to $7.0 \mathrm{~mm}$. Without $\mathrm{Ag}$, the $\mathrm{La}-\mathrm{Cu}-\mathrm{Al}$ ternary alloys are distinctly crystallized for the rods of 3.0 and $4.0 \mathrm{~mm}$ in diameter and their critical diameters are below $3 \mathrm{~mm}$ as shown in Table 1. With 5 at\% of Ag addition, the glassy alloy rods with larger diameters have been successfully prepared, and the best GFA is achieved for $\mathrm{La}_{62.5} \mathrm{Al}_{12.5} \mathrm{Cu}_{20} \mathrm{Ag}_{5}$ which has a critical casting diameters above $6 \mathrm{~mm}$. This indicates that the appropriate amount of $\mathrm{Ag}$ addition prevents the

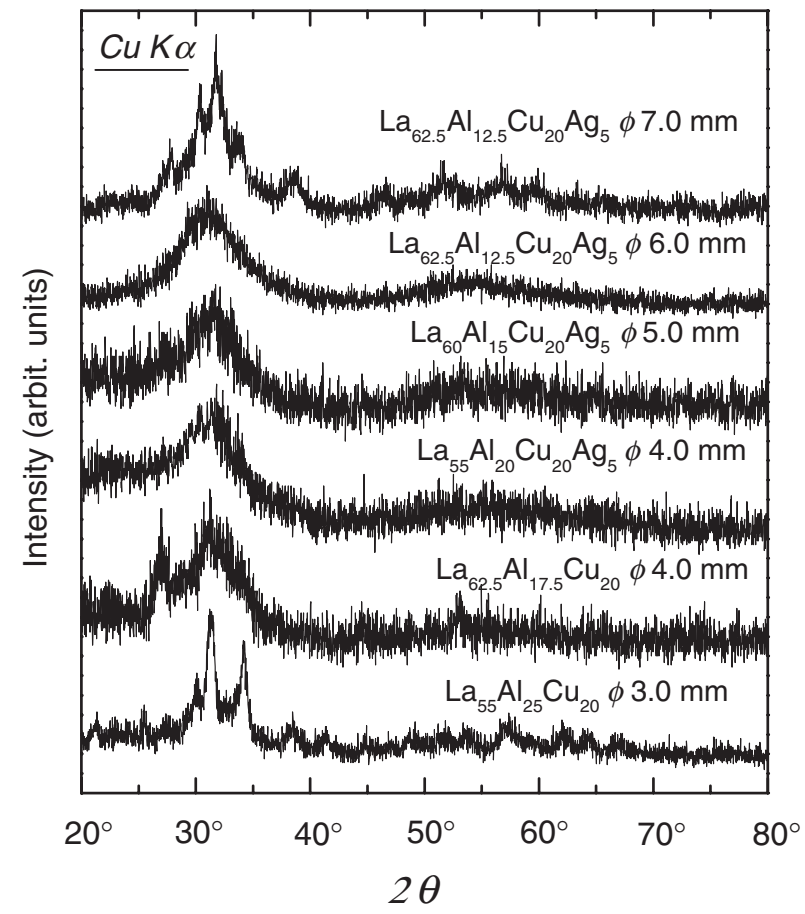

Fig. 4 X-ray diffraction patterns of cast La-Al-Cu and La-Al-Cu-Ag alloy rods with diameters of 3-7 $\mathrm{mm}$.

formation of intermetallic compounds, yielding fully glassy samples. It has been noticed that the highest GFA of the present quaternary alloy series, especially the $\mathrm{La}_{62.5} \mathrm{Al}_{12.5^{-}}$ $\mathrm{Cu}_{20} \mathrm{Ag}_{5}$ alloy, comes in most part from the alloying effect of $\mathrm{Ag}$, which lowers the liquidus temperature of the matrix alloy and brings the composition to a deeper eutectic valley (Fig. 3). From a kinetic aspect, there are multiple ordered phases competing with each other for eutectic alloys in multicomponent systems, and the crystallization of the liquid requires simultaneous rearrangements of different species of atoms, which significantly suppresses the kinetics of the crystallization process and thus promotes glass formation. ${ }^{27)}$ The empirical component rules drawn from experimental results $^{20)}$ have demonstrated that certain atomic-size mismatch and efficient atomic packing enhance GFA of multicomponent systems. In the $\mathrm{La}-\mathrm{Cu}-\mathrm{Al}-\mathrm{Ag}$ system, the atomic radii of the component elements are La, $1.88 \AA$; $\mathrm{Ag}, 1.45 \AA$; $\mathrm{Al}, 1.43 \AA$ and $\mathrm{Cu}, 1.27 \AA$, respectively, ${ }^{28)}$ and hence the atomic size ratios are 1.48 for $\mathrm{La} / \mathrm{Cu}, 1.30$ for $\mathrm{La} / \mathrm{Ag}$, and 1.32 for $\mathrm{Ag} / \mathrm{Cu}$. Therefore, the present combination of atomic sizes can produce an efficiently packed local structure, which is often associated with low internal energy and high viscosity of liquid. In addition, in the present system, this criterion is also satisfied because the heats of mixing for $\mathrm{La}-\mathrm{Al}, \mathrm{La}-\mathrm{Cu}$, and $\mathrm{La}-\mathrm{Ag}$ pairs are $-38,-22$, and $-21 \mathrm{~kJ}=$ mol, respectively. ${ }^{29)}$ These large negative values of the heat of mixing enhance the interactions among the components and promote chemical short range ordering in liquids, which can improve the local packing efficiency and restrain long range diffusion of atoms.

3.3 Multi-component $\mathrm{La}-\mathrm{Al}-(\mathrm{Cu}, \mathrm{Co}, \mathrm{Ni})-\mathrm{Ag}$ glassy alloys A small amount of $\mathrm{Co}$ or $\mathrm{Ni}$ addition was found to further 


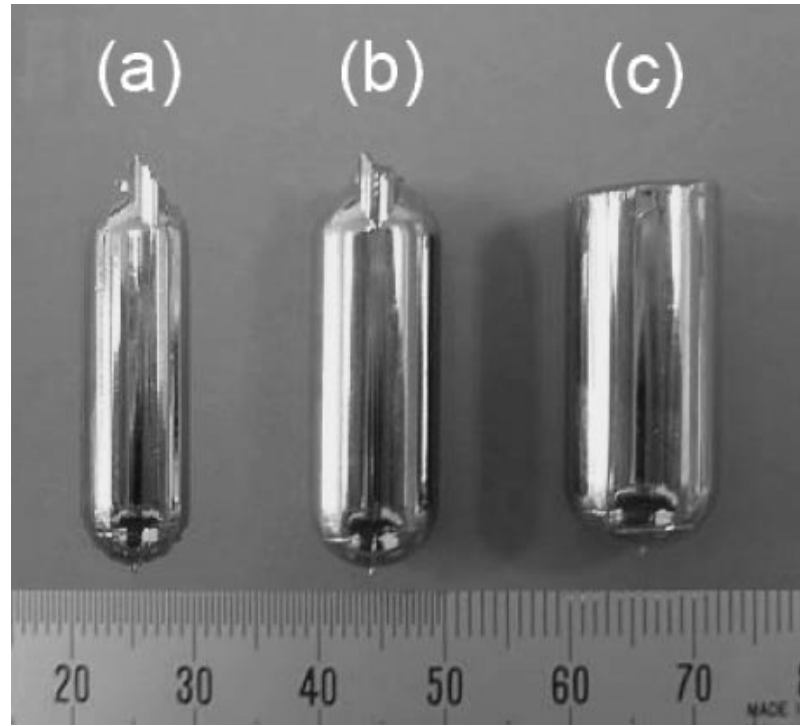

Fig. 5 Shape and outer surface appearance of cast $\mathrm{La}-\mathrm{Al}-(\mathrm{Cu}, \mathrm{Co}, \mathrm{Ni})-\mathrm{Ag}$ alloy rods with diameters of 8-12 mm. (a) $\mathrm{La}_{62.5} \mathrm{Al}_{12.5} \mathrm{Cu}_{15} \mathrm{Ni}_{5} \mathrm{Ag}_{5}$, (b) $\mathrm{La}_{62.5} \mathrm{Al}_{12.5} \mathrm{Cu}_{12.5} \mathrm{Ni}_{2.5} \mathrm{Co}_{5} \mathrm{Ag}_{5}$, (c) $\mathrm{La}_{62.5} \mathrm{Al}_{12.5} \mathrm{Cu}_{10} \mathrm{Ni}_{5} \mathrm{Co}_{5} \mathrm{Ag}_{5}$.

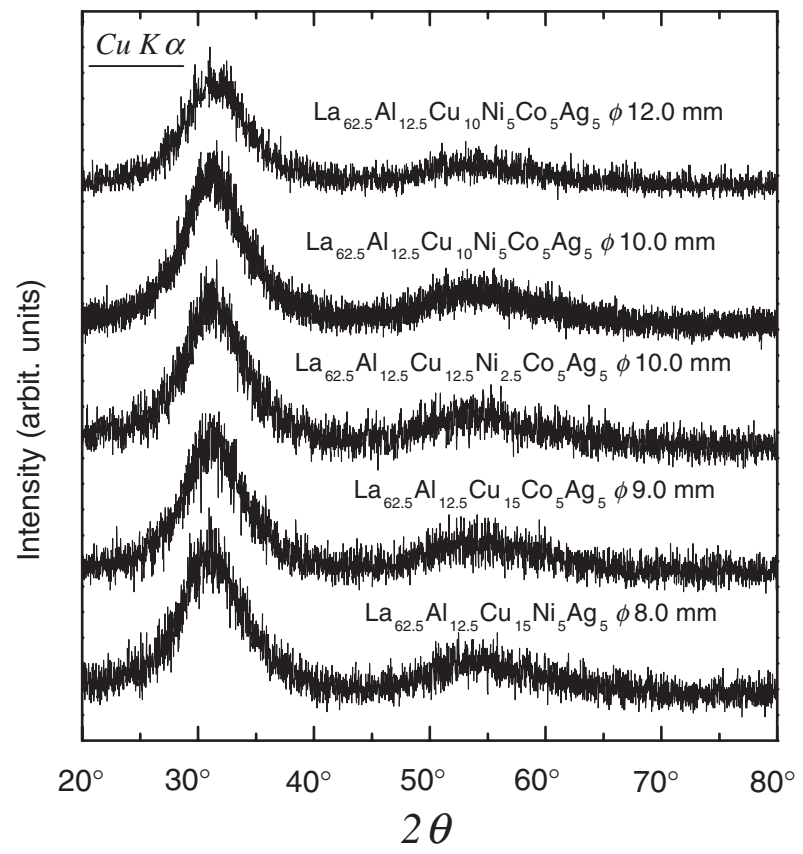

Fig. 6 X-ray diffraction patterns of casst $\mathrm{La}-\mathrm{Al}-(\mathrm{Cu}, \mathrm{Co}, \mathrm{Ni})-\mathrm{Ag}$ alloy rods with diameter of $8-12 \mathrm{~mm}$.

improve the GFA. Figures 5 and 6 show the outer shape and surface appearance and X-ray diffraction patterns of the ascast $\mathrm{La}-\mathrm{Al}-\mathrm{Ag}-(\mathrm{Cu}, \mathrm{Co}, \mathrm{Ni})$ alloy rods with diameters ranging from 8 to $12 \mathrm{~mm}$. The surfaces of the rods are smooth and neither concaveness nor cavity can be seen. All XRD patterns consist only of broad peaks, and no diffraction peak corresponding to a crystalline phase is seen, indicating that the glassy alloy ros are formed in the diameter range up to $12 \mathrm{~mm}$. Figures 7 and 8 show DSC and DTA curves of the La-Al-Ag- $(\mathrm{Cu}, \mathrm{Co}, \mathrm{Ni})$ glassy alloys. As seen from these DSC scans as well as from Table 1 , the $\Delta T_{x}$ remarkably increases by a small amount of $\mathrm{Ni}$ addition and the largest

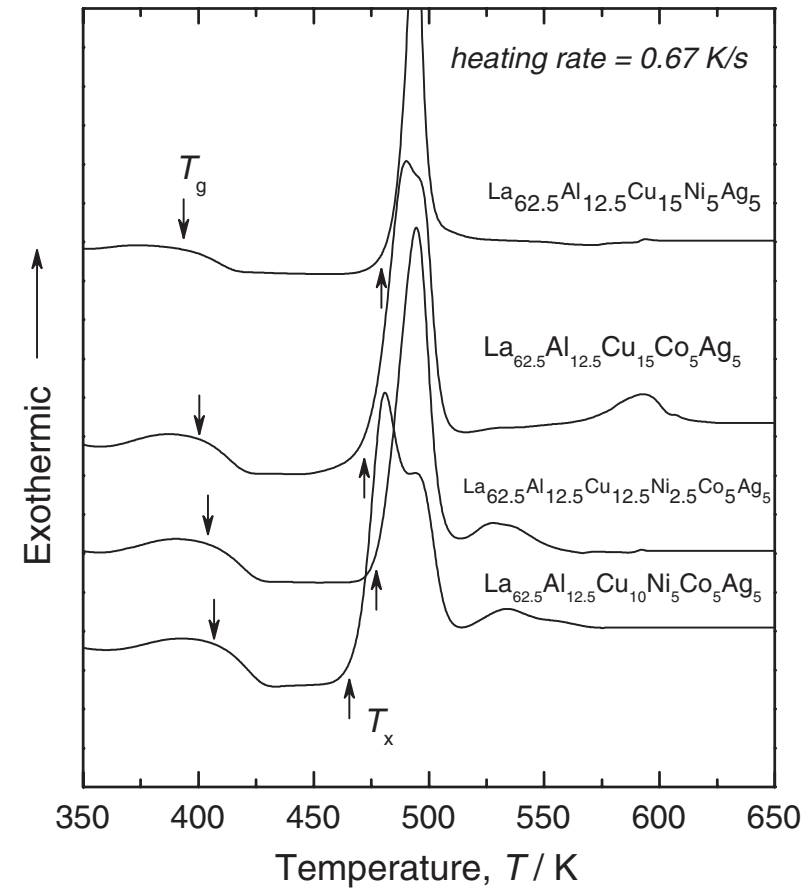

Fig. 7 DSC curves of melt-spun La-Al-(Cu, Co, Ni)-Ag glassy alloys.

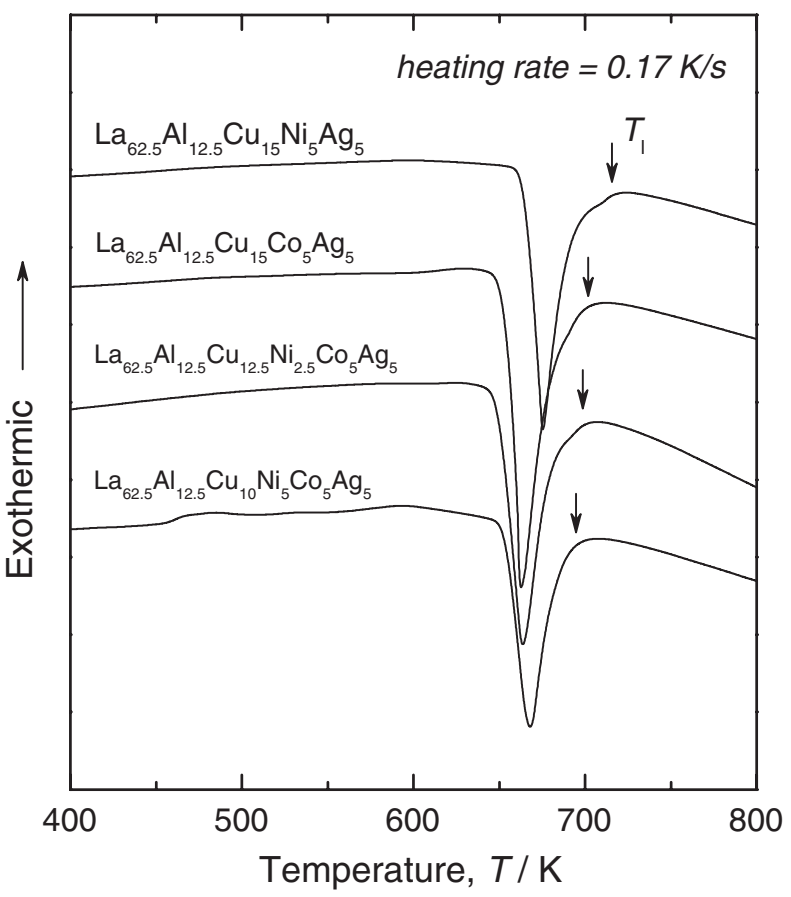

Fig. 8 DTA curves of the La-Al-(Cu, Co, Ni)-Ag alloys.

$\Delta T_{x}$ of $96 \mathrm{~K}$ was obtained for $\mathrm{La}_{62.5} \mathrm{Al}_{12.5} \mathrm{Cu}_{15} \mathrm{Ni}_{5} \mathrm{Ag}_{5}$ alloy. However, the $\Delta T_{x}$ value decrease by a small amount of Co addition. In addition, it is noticed that all the $T_{g}$ slightly increase by the Ni or Co addition. From Fig. 8 and Table 1, it is seen that the $T_{l}$ values of the $\mathrm{La}-\mathrm{Cu}-\mathrm{Al}-\mathrm{Ag}$ alloys decrease by a small amount of $\mathrm{Ni}$ or Co addition. The $\mathrm{La}_{62.5^{-}}$ $\mathrm{Al}_{12.5} \mathrm{Cu}_{10} \mathrm{Ni}_{5} \mathrm{Co}_{5} \mathrm{Ag}_{5}$ glassy alloy shows the lowest $T_{l}$ of $691 \mathrm{~K}$, resulting in the highest $T_{g} / T_{l}$ of 0.585 , leading to the formation of the glassy sample with largest critical diameter above $12 \mathrm{~mm}$. Based on Table 1, the critical sample 
diameters $\left(d_{c}\right)$ of the present glassy alloys are plotted as a function of $T_{g} / T_{l}$, as shown in Fig. 9. A good correlatio between the $d_{c}$ and $T_{g} / T_{l}$ is recognized, suggesting that the $T_{g} / T_{l}$ is closely related to the GFA of the La-based glassy alloys. On the other hand, with the aim of obtaining at a better description of the GFA of various glassy alloys, the parameters, including $\Delta T_{x}{ }^{20)}$ and $\gamma\left(T_{x} /\left(T_{g}+T_{l}\right),{ }^{30)}\right.$ have been utilized by different researchers. However, as is evident from Table 1, we cannot see that the present glassy alloys have good correlation between GFA and $\Delta T_{x}$ or $\gamma$.

\subsection{Mechanical properties of La-based bulk glassy alloys}

Figure 10 shows compressive stress-strain curves of the La-based glassy alloy rods with a diameter of $2.0 \mathrm{~mm}$. The glassy alloys exhibit high fracture strengths of over $640 \mathrm{MPa}$ and distinct plastic strains. Table 1 summarizes mechanical properties of bulk glassy La-based glassy alloys. The bulk glassy alloys possess good mechanical properties, i.e., compressive fracture strength $\left(\sigma_{c, f}\right)$ of $640-858 \mathrm{MPa}$, Young's modulus $(E)$ of $36-46 \mathrm{GPa}$, compressive elastic

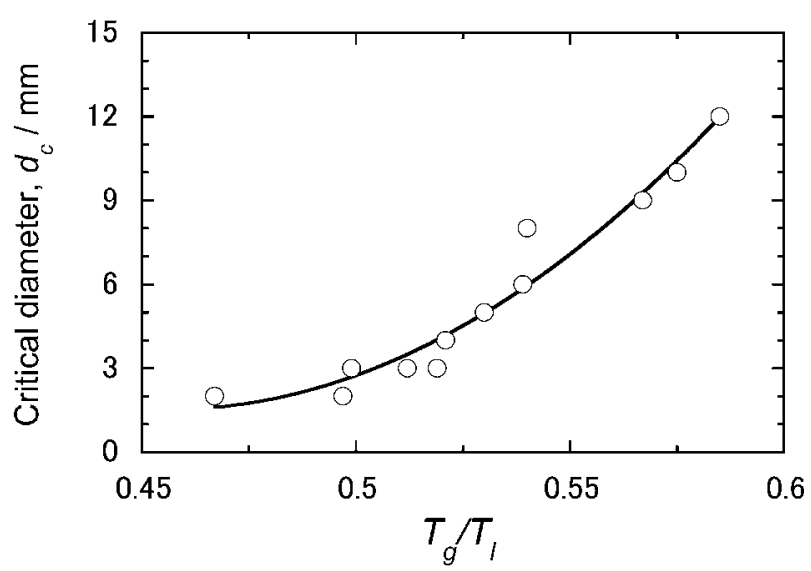

Fig. 9 The critical diameters as a function of $T_{g} / T_{l}$ for the La-based bulk glassy alloys. strain $\left(\varepsilon_{c, e}\right)$ of $1.7-1.9 \%$, plastic strain $\left(\varepsilon_{c, p}\right)$ of $0.2-0.4 \%$ and Vickers hardness $\left(H_{v}\right)$ of 201-228. The fracture behavior and fracture surface appearance are exemplified for the $\mathrm{La}_{55} \mathrm{Al}_{20} \mathrm{Cu}_{20} \mathrm{Ag}_{5}$ glassy alloy rod in Fig. 11. The fracture occurs along the maximum shear stress plane, which is declined by about 45 degrees to the direction of applied load (Fig. 11(a)), and the fracture surface consists mainly of a well-developed vein pattern (Fig. 11(b)) typical to other bulk glassy alloys with good ductility. ${ }^{12,20)}$ Many shear deformation bands are also observed on the rod surface (Fig. 11(c)). The distinct plastic strain can thus be attributed to the generation of many shear deformation bands.

\section{Conclusions}

We examined the thermal stability, GFA and mechanical properties of La-based La-Al-Cu-Ag and $\mathrm{La}-\mathrm{Al}-(\mathrm{Cu}, \mathrm{Ni}, \mathrm{Co})-$ $\mathrm{Ag}$ glassy alloys, based on the fundamental knowledge

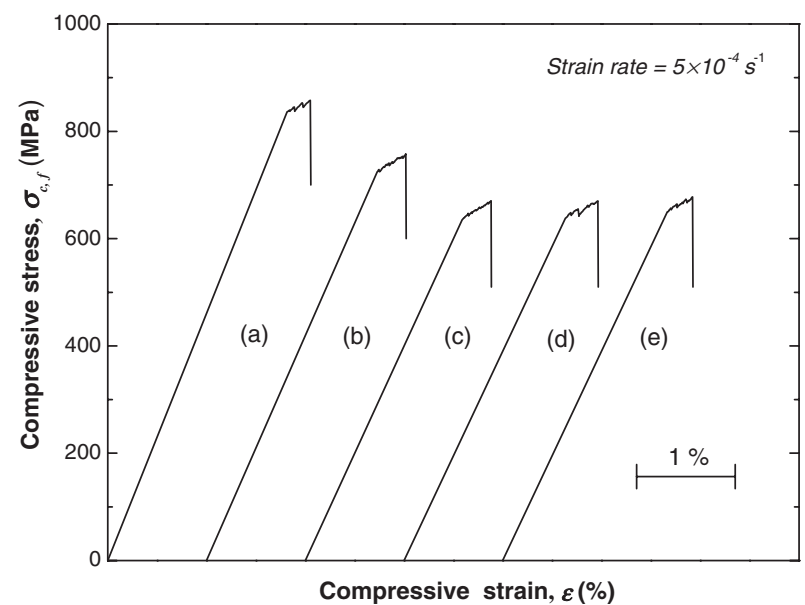

Fig. 10 Compressive stress-strain curves of cast La-based glassy alloy rods with a diameter of $2.0 \mathrm{~mm}$. (a) $\mathrm{La}_{55} \mathrm{Al}_{25} \mathrm{Cu}_{20}$, (b) $\mathrm{La}_{55} \mathrm{Al}_{20} \mathrm{Cu}_{20} \mathrm{Ag}_{5}$, (c) $\mathrm{La}_{62.5} \mathrm{Al}_{12.5} \mathrm{Cu}_{15} \mathrm{Ni}_{5} \mathrm{Ag}_{5}$, (d) $\mathrm{La}_{62.5} \mathrm{Al}_{12.5} \mathrm{Cu}_{15} \mathrm{Co}_{5} \mathrm{Ag}_{5}$, (e) $\mathrm{La}_{62.5-}$ $\mathrm{Al}_{12.5} \mathrm{Cu}_{10} \mathrm{Ni}_{5} \mathrm{Co}_{5} \mathrm{Ag}_{5}$.
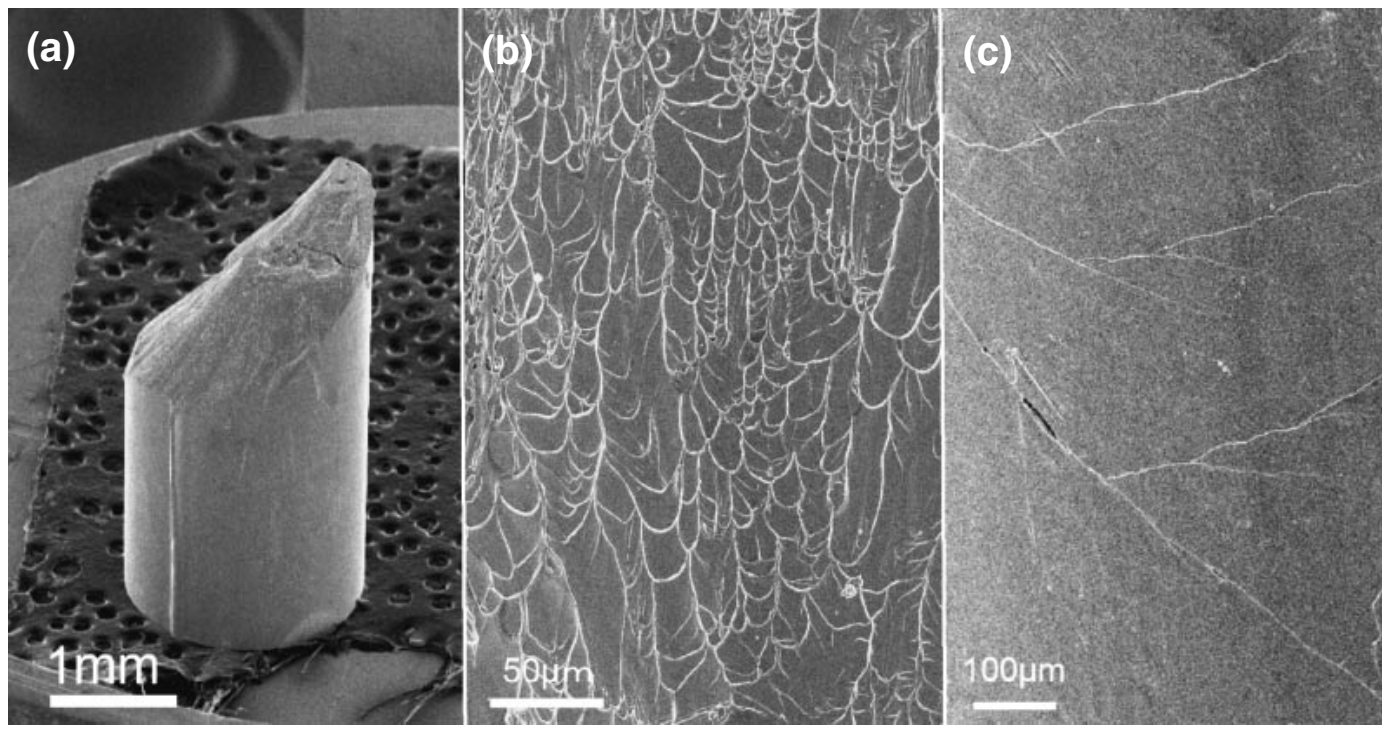

Fig. 11 Fracture surface appearance of the cast $\mathrm{La}_{55} \mathrm{Al}_{20} \mathrm{Cu}_{20} \mathrm{Ag}_{5}$ glassy alloy rod. 
La-Al-Cu ternary glassy alloys, with the aim of searching for a new bulk glassy system with high GFA. The results obtained are summarized as follows.

(1) The addition of 5 at\% Ag to La-Al-Cu alloys greatly increases the stability of supercooled liquid and $T_{g} / T_{l}$. The largest $\Delta T_{x}$ of $83 \mathrm{~K}$ and $T_{g} / T_{l}$ of 0.539 were obtained for the $\mathrm{La}_{62.5} \mathrm{Cu}_{20} \mathrm{Al}_{12.5} \mathrm{Ag}_{5}$ alloy, leading to the formation of the glassy rods with diameters up to $6 \mathrm{~mm}$ by copper mold casting.

(2) The addition of a small amount of $\mathrm{Ni}$ or Co to La-Al$\mathrm{Ag}-\mathrm{Cu}$ alloys increases $T_{g}$ and lowers $T_{l}$, resulting in the higher $T_{g} / T_{l}$ values of over 0.540 . The best GFA was achieved for $\mathrm{La}_{62.5} \mathrm{Al}_{12.5} \mathrm{Cu}_{10} \mathrm{Ni}_{5} \mathrm{Co}_{5} \mathrm{Ag}_{5}$ alloy and its critical sample diameter was over $12 \mathrm{~mm}$.

(3) The GFA of the La-based alloys is more closely related with $T_{g} / T_{l}$ values rather than the $\Delta T_{x}$ or $\gamma$.

(4) The bulk glassy alloys exhibited good mechanical properties, i.e., compressive fracture strength of 640 $858 \mathrm{MPa}$, Young's modulus $(E)$ of $36-46 \mathrm{GPa}$, plastic strain of $0.2-0.4 \%$ and Vickers hardness $\left(H_{v}\right)$ of $201-$ 228. The new La-based glassy alloys with high GFA, low $T_{g}$, wide $\Delta T_{x}$ and good mechanical properties may have useful engineering applications in the future.

\section{Acknowledgements}

This work was financially supported by Research and Development Project on Advanced Metallic Glasses, Inorganic Materials and Joining Technology from the Ministry of Education, Science, Sports, and Culture of Japan.

\section{REFERENCES}

1) A. Inoue, K. Kita, T. Zhang and T. Masumoto: Mater. Trans., JIM 30 (1989) 722-725.

2) A. Inoue, A. Kato, T. Zhang, S. G. Kim and T. Masumoto: Mater. Trans., JIM 32 (1991) 609-616.
3) T. Zhang, A. Inoue and T. Masumoto: Mater. Trans., JIM 32 (1991) 1005-1010.

4) A. Peker and W. L. Johnson: Appl. Phys. Lett. 63 (1993) 2342-2344.

5) A. Inoue and J. S. Gook: Mater. Trans., JIM 36 (1995) 1180-1183.

6) A. Inoue, N. Nishiyama and T. Matsuda: Mater. Trans., JIM 37 (1996) $181-184$.

7) T. Zhang and A. Inoue: Mater. Trans., JIM 39 (1998) 1001-1006.

8) T. Itoi and A. Inoue: Mater. Trans., JIM 41 (2000) 1256-1262.

9) X. Wang, I. Yoshii, A. Inoue, Y. H. Kim and I. B. Kim: Mater. Trans., JIM 40 (1999) 1130-1136.

10) S. Yi, T. G. Park and D. H. Kim: J. Mater. Res. 15 (2000) 2425-2430.

11) T. Zhang and A. Inoue: Mater. Trans. 43 (2002) 708-711.

12) A. Inoue, W. Zhang, T. Zhang and K. Kurosaka: Acta Mater. 49 (2001) 2645-2652.

13) A. Inoue and W. Zhang: Mater. Trans. 43 (2002) 2921-2925.

14) W. Zhang and A. Inoue: J. Mater. Res. 21 (2006) 234-241.

15) J. Schroers and W. L. Johnson: Appl. Phys. Lett. 84 (2004) 3666-3668.

16) J. Schroers, B. Lohwongwatana, W. L. Johnson and A. Peker: Appl. Phys. Lett. 87 (2005) 061912-1-061912-3.

17) W. L. Johnson: Mater. Sci. Forum. 225 (1997) 35-40.

18) A. Inoue: Acta Mater. 48 (2000) 279-306.

19) A. Inoue, Y. Kawamura and Y. Saotome: Mater. Sci. Forum. 233-234 (1997) 147-152.

20) A. Inoue: Mater. Trans., JIM 36 (1995) 866-875.

21) A. Inoue, T. Zhang and T. Masumoto: Mater. Trans., JIM 30 (1989) 965-972.

22) A. Inoue, T. Zhang, W. Zhang and A. Takeuchi: Mater. Trans., JIM 37 (1996) 636-640.

23) F. Guo, S. J. Poon and G. J. Shiflet: Appl. Phys. Lett. 83 (2003) 25752577.

24) R. Li, S. Pang, H. Men, C. Ma and T. Zhang: Scripta. Mater. 54 (2006) 1123-1126.

25) B. Zhang, M. X. Pan, D. Q. Zhang and W. H. Wang: Appl. Phys. Lett. 85 (2004) 61-63.

26) A. Inoue, T. Nakamura, T. Sugita, T. Zhang and T. Masumoto: Mater. Trans., JIM 34 (1993) 351-358.

27) D. H. Xu, G. Duan and W. L. Johnson: Phys. Rew. Lett. 92 (2004) 245504-1-245504-4.

28) Metals Databook, ed. by Japan Inst. Metals, (Maruzen, Tokyo, 1983) p. 8.

29) F. R. Niessen: Cohesion in Metals, (Elsevier Science Publishers, Amsterdam, 1988) p. 224.

30) Z. P. Lu and C. T. Liu: Acta Mater. 50 (2002) 3501-3512. 